University of Nebraska - Lincoln

DigitalCommons@University of Nebraska - Lincoln

Papers in the Earth and Atmospheric Sciences Earth and Atmospheric Sciences, Department

5-1942

\title{
Parabos dodsoni Barbour and Schultz: A Correction
}

\author{
Erwin Hinckley Barbour \\ University of Nebraska-Lincoln \\ C. Bertrand Schultz \\ University of Nebraska State Museum
}

Follow this and additional works at: https://digitalcommons.unl.edu/geosciencefacpub

Part of the Earth Sciences Commons

Barbour, Erwin Hinckley and Schultz, C. Bertrand, "Parabos dodsoni Barbour and Schultz: A Correction" (1942). Papers in the Earth and Atmospheric Sciences. 339.

https://digitalcommons.unl.edu/geosciencefacpub/339

This Article is brought to you for free and open access by the Earth and Atmospheric Sciences, Department of at DigitalCommons@University of Nebraska - Lincoln. It has been accepted for inclusion in Papers in the Earth and Atmospheric Sciences by an authorized administrator of DigitalCommons@University of Nebraska - Lincoln. 
PARABOS DODSONI BARBOUR AND SCHULTZ: A Correction

A Bos-like animal, Parabos dodsoni, was recently described by Barbour and Schultz (1941, "A New Fossil Bovid from Nebraska", Bull. Univ. Nebr. State Museum, Vol. II, No. 7, pp. 63-66, Figs. 24-27, December) as a new genus and species from the Pleistocene of Nebraska. Attention has been called to the writers by Dr. E. H. Colbert of the American Museum of Natural History that the name Parabos is preoccupied. Parabos was introduced as a generic name by C. Arambourg and J. Piveteau (1929, "Note preliminaire sur un Ruminant du Pliocene inferieur du Roussillon," C. R. Bull. Soc. Geol. de France, 4th Ser., XXIX, pp. 144-146). Unfortunately the reference was missed by the present writers as well as by the editors of the Zoological Record (1929-1939).

The writers propose the name Platycerabos to replace Parabos for the new American bovid. The corrected designation would thus be Platycerabos dodsoni (Barbour and Schultz).

The occurrence of a Bos-like form from the Pleistocene of North America is unique. It has long been thought that the migration of true bovines from Asia to North America during the Pleistocene was limited to Bison, but the discovery of Platycerabos dodsoni has altered this belief.-Erwin Hinckley Barbour and C. Bertrand Schultz, University of Nebraska State Museum, Lincoln, Nebraska. 